\title{
Dataset Paper \\ Long-Term Data from Fields Recovering after Sugarcane, Banana, and Pasture Cultivation in Ecuador
}

\author{
Randall W. Myster \\ Biology Department, Oklahoma State University, Oklahoma City, OK 73017, USA \\ Correspondence should be addressed to Randall W. Myster; rwmyster@gmail.com
}

Received 2 April 2012; Accepted 28 May 2012

Academic Editors: A. Arunachalam, A. Etter, and O. J. Sun

Copyright (C) 2013 Randall W. Myster. This is an open access article distributed under the Creative Commons Attribution License, which permits unrestricted use, distribution, and reproduction in any medium, provided the original work is properly cited.

I report here on an ongoing permanent plot study in areas recovering from agriculture in Ecuador. These plots were set up in 1995 at Maquipucuna Reserve where the forest is tropical lower montane. The study consists of replicate fields in three past crop types (Sugarcane, Banana, and Pasture) for a total of six fields. Each field was first divided into 25 continuous $2 \mathrm{~m} \times 5 \mathrm{~m}$ subplots which together form a $10 \mathrm{~m} \times 25 \mathrm{~m}$ plot with the longest side bordering the adjacent forest. Then starting in 1996, and continuing annually every year since, each subplot has been sampled for percent cover of all plants and diameter at breast height (dbh) for all trees whose dbh is greater than or equal to $1 \mathrm{~cm}$. I have used that data in these published studies: (1) species composition and life form, richness, and basal area trends, (2) computation of all positive and negative pairwise species associations, (3) relationships between richness and productivity over time, (4) dominance-diversity curves, and (5) definition and quantification of old field plant communities. Finally with the help of the LTER program in Puerto Rico, this sampling continues, with 2012 marking the sixteenth year of continuous annual sampling.

\section{Introduction}

Conducted for decades over many of the most common gradients on earth, studies of succession after agriculture-also called postagricultural or old field succession-have helped ecologists gain insights into the processes that structure plant communities and into the role of history and initial conditions in community development $[1,2]$. Examination of old fields has led to the rise of important ecological theories, such as the initial floristic composition hypothesis [3] and the resource ratio hypothesis [4]. Using permanent plots [5] established at abandonment as the backbone of old field research (e.g., the Buell-Small old field plot study in New Jersey, USA [6,7]), scientists have been successful in finding the pattern of response over time after abandonment from crops [8] and in discovering many of the mechanisms that determine the pattern $[9,10]$. Furthermore, studies of postagricultural succession have provided a framework for comparison and evaluation of various theories of succession and community development [11].

A considerable amount of old field and pasture research has taken place in the temperate regions of the United States
$[4,6,9,12-16]$ and Europe $[15,16]$. The recovery of agricultural areas, however, is vital to ecosystems all over the world [17], where they form ecotones between forest and grasslands [18]. Particularly in the Tropics, the cutting down of wooded areas $[19,20]$ for agriculture and pasture $[21]$ is the major cause of deforestation [20, 22-24]. Consequently, recovery of Neotropical areas after agriculture [25-27] is relevant to such important issues as forest regeneration $[19,21,28-$ $30]$, forest ecosystem restoration $[28,31]$, sustainability of agriculture [28, 32], maintenance of biodiversity [28, 33], and impacts of global climate change on forest dynamics [3437]. Neotropical areas recovering from agriculture may also serve as a buffer between primary forest and more intensely human-influenced areas [28]. Finally with future increase of global warming and other human-induced effects, forest disturbances like old field succession should affect larger and larger parts of the earth [10].

The nature of the recovery of old fields depends on their disturbance regime, which is characterized by severity, size, spatial location, and frequency [38]. The measurement of severity may be best accomplished by sampling the loss of plant biomass and determining whether such loss includes 
loss of plant meristems $[4,39,40]$. Severity of old fields is moderate, compared to the more severe landslides [41, 42] and the less severe treefall [43] because old fields maintain an intact soil profile, roots, and humus layer despite the removal of above-ground vegetation. In size, old fields do not usually exceed a few tens of hectares (they are larger, however, than many Neotropic treefall gaps [44]), and crops that are planted in them often require specific locations (e.g., Coffee grows well in the mountains while Banana and Sugarcane do best in the valleys).

Frequency of old field disturbance includes the number of times a field has been cultivated, the duration of each cropping period, the time between fallow periods, and the order of crop rotation. Usually fields are fallow longer than they are in crop and can be either reused with different crops and fallow periods until abandoned or used for 5-10 years until productivity declines [45]. As the length of time an area is in crop increases, the length of successional, or recovery, time may also lengthen. For example, a short cropping period can lead to large contributions from the seed bank, and trees may regenerate quickly from stump or root sprouts whereas an increased cropping period brings about the decay of rootstocks and tree stumps, thus providing for grass invasion and prolonged tree invasion. Among other conditions that influence old field recovery are historical effects of the past crop (a crop's signature $[1,2,46]$ ), the year of abandonment, the season of abandonment, the percent of border with forest [13], and a field's plowing record (whether the field was plowed under or left fallow when abandoned [7]).

Studies of postagricultural succession in the temperate zone have demonstrated the particular importance of past crops in determining old field patterns (e.g., alteration of successional pathways and species composition and abundance for up to 8 years after abandonment $[1,2,46])$. Hence, I focused in this Neotropical study on the examination of fields after common Neotropic crops, such as Sugarcane (Saccharum officinarum), Banana (Musa spp.), and Coffee (Coffea spp. (see Puerto Rico studies reviewed in [38]), and after pasture grasses that usually establish themselves after cropping but can also be purposely planted (e.g., Setaria sphacelata). Pastures are a kind of old field succession for several reasons. First, they are usually converted from depleted agricultural fields when cows are allowed to enter. Second, they may continue to have remnants of the previous past crops growing in them for some years. Third, they can be planted with exotic grasses or be colonized by local grass species due to cattle activity (e.g., trampling of vegetation, creation of hummocks, deposition of dung, and soil compaction).

For the studies reported here, all fields were first cleared from forest using shifting or "slash and burn" [47] agriculture, which occurs when natural vegetation is first cut down to the ground and then burnt. Although burning produces a short pulse of nutrients like phosphorus, it generally volatilizes both organic matter and nitrogen while raising soil temperature and, in the long term, makes soil poor in both nutrients and the seed bank. Shifting agriculture also entails a rotation of fields rather than crops that is accompanied by long fallow periods. The decision as to when to rotate fields and for how long to leave them fallow depends on such factors as weed and insect loads in the fields, soil fertility, production, labor availability, and local dietary needs [45]. This forestclearing method causes carbon loss, a mixing of the soil horizons, and a higher degree of soil aeration [10]. Shifting agriculture also lowers the level of advanced regeneration from sapling banks and from root/stem resprouting so that seed and seedling dynamics [48] dominate regeneration after agriculture.

Old field recovery goes through several structural and conceptual stages: (1) domination by past crop and its various effects, (2) patch dynamics of grass, past crop remnants, asexual shrubs, and other plants, (3) tree invasion, and (4) development of a closed-canopy secondary forest. After a closed canopy has developed, old field plants may eventually enter a thinning state when dead plants in the canopy are replaced not with new individuals but with modified growth of existing plants. There is a physiological limit to this kind of growth, however, and at some point every plant will die and be replaced. Indeed plants are always involved in the on-going dynamic process of plant-plant replacement $[49,50]$. Plantplant replacement does not necessarily, however, involve two plants only for more than one plant can be replaced by just one or only one plant can be replaced by more than one. As plant-plant replacements proceed, the two spaces each plant has (its phytospace defined by its biomass and necromass, and its surrounding neighborhood space) can be occupied and reoccupied. Because plant replacements occur slowly, permanent plots are needed in order to sample the dynamic replacements all plants are engaged in.

Replacements create changes in plant abundances, which may also create changes in plant composition that lead to the emergence of other patterns at larger spatial and temporal scales (e.g., successional rate and direction, patch dynamics, plant distribution, exotic plant invasion, and plant associations (Tables 1-6)). Care must be taken, however, with the observation of these plant patterns. For example, even though individual plants continue to be replaced, preservation of species abundances and/or species composition at a larger scale of organization may still occur, giving the impression of a coexistence of species (when the identity or the number of plant species remains the same despite changes in plant abundances) or of a plant community at equilibrium (when neither plant species nor plant abundances change). Existence of high-level patterns that do not change very much over time should not obscure the fact that such patterns are the product of a dynamic and ever-changing process of plantplant replacement. Any plant pattern is only a snapshot of the vegetation at a given instance in time and at a specific scale of observation whereas plant-plant replacements occur continuously.

Replacements are controlled by species tolerances and mechanisms which affect plant growth and the definition of plant spaces. Tolerances include germination and growth while mechanisms encompass dispersal, seed pool, seed predation, seed pathogens, seed germination, seedling predation, seedling pathogens, seedling herbivory, and/or seedling competition [51-55]. The process of plant-plant replacement is at the heart of the dynamic nature of terrestrial plant communities both over successional time and over space 
TABLE 1: Significant Spearman rank correlation coefficients among all plant species in the Left Banana Plantation over the first 10 years of succession. Significant positive associations are indicated by a “+” and significant negative associations are indicated by a “-”. Plant species and families are indicated as follows: Acalypha pladichephalus (A), Begonia spp. (B), Geonoma undata (C), Cyathea spp. (D), Musa spp. (E), Pilea spp. (F), Anthurium spp. (G), Trichipterix pilosissima (H), Nectandra spp. (I), Ochroma spp. (J), Baccharis spp. (K), Anthurium spp. (L), Setaria spp. (M), Boconia frutescens (N), Piper aduncum (O), Erythrina megistophyla (P), Vernonia patens (Q), Hedyosum spp. (R), Commelina diffusa (S), Althernantera spp. (T), Siparuna piloso-lepidota (U), Solanum spp. (V), Vernonia spp. (W), Digitaria sanguinalis (X), Inga spp. (Y), and Passiflora spp. (Z).

\begin{tabular}{|c|c|c|c|c|c|c|c|c|c|c|c|c|c|c|c|c|c|c|c|c|c|c|c|c|c|}
\hline & B & C & $\mathrm{D}$ & $\mathrm{E}$ & $\mathrm{F}$ & $\mathrm{G}$ & $\mathrm{H}$ & I & $\mathrm{J}$ & $\mathrm{K}$ & $\mathrm{L}$ & $\mathrm{M}$ & $\mathrm{N}$ & $\mathrm{O}$ & $\mathrm{P}$ & $\mathrm{Q}$ & $\mathrm{R}$ & $S$ & $\mathrm{~T}$ & $\mathrm{U}$ & $\mathrm{V}$ & $\mathrm{W}$ & $\mathrm{X}$ & $\mathrm{Y}$ & $\mathrm{Z}$ \\
\hline A & + & + & + & + & + & + & + & - & + & + & + & + & - & + & + & + & + & + & & & & & & & \\
\hline B & & + & + & + & + & + & + & + & + & + & + & + & + & + & + & + & + & + & - & + & + & + & & & \\
\hline C & & & + & + & + & + & + & + & + & + & + & + & + & + & + & - & - & & & & & & & & \\
\hline $\mathrm{D}$ & & & & + & + & + & + & + & + & - & + & - & + & & & & & & & & & & & & \\
\hline $\mathrm{E}$ & & & & & + & + & + & + & + & + & & & & & & & & & & & & & & & \\
\hline $\mathrm{F}$ & & & & & & + & + & + & + & + & + & - & + & + & & & & & & & & & & & \\
\hline $\mathrm{G}$ & & & & & & & + & + & + & + & + & + & + & - & + & & & & & & & & & & \\
\hline $\mathrm{H}$ & & & & & & & & + & + & + & + & + & + & + & + & + & + & + & & & & & & & \\
\hline I & & & & & & & & & + & + & - & + & & & & & & & & & & & & & \\
\hline $\mathrm{J}$ & & & & & & & & & & + & + & + & + & + & - & + & + & + & + & + & + & + & + & & \\
\hline $\mathrm{K}$ & & & & & & & & & & & & + & + & + & + & + & + & + & + & & & & & & \\
\hline $\mathrm{L}$ & & & & & & & & & & & & & + & + & + & + & + & + & & & & & & & \\
\hline $\mathrm{M}$ & & & & & & & & & & & & & & + & + & & & & & & & & & & \\
\hline $\mathrm{N}$ & & & & & & & & & & & & & & & + & & & & & & & & & & \\
\hline $\mathrm{O}$ & & & & & & & & & & & & & & & & + & + & + & + & - & & & & & \\
\hline $\mathrm{P}$ & & & & & & & & & & & & & & & & & + & + & + & & & & & & \\
\hline Q & & & & & & & & & & & & & & & & & & + & + & + & + & + & + & & \\
\hline $\mathrm{R}$ & & & & & & & & & & & & & & & & & & & + & + & + & + & & & \\
\hline S & & & & & & & & & & & & & & & & & & & & + & + & + & & & \\
\hline $\mathrm{T}$ & & & & & & & & & & & & & & & & & & & & & + & + & & & \\
\hline $\mathrm{U}$ & & & & & & & & & & & & & & & & & & & & & + & + & + & + & + \\
\hline $\mathrm{V}$ & & & & & & & & & & & & & & & & & & & & & & + & + & & \\
\hline W & & & & & & & & & & & & & & & & & & & & & + & + & + & + & + \\
\hline $\mathrm{X}$ & & & & & & & & & & & & & & & & & & & & & & + & + & & \\
\hline
\end{tabular}

(e.g., at the edges of plant distributions where gradients have a major effect on plants [56]). It seems that plants wait not to be counted (sensu [57]) but to be replaced! Thus the ultimate reality of plant communities is the plant-plant replacements, for they produce vegetation patterns at all larger temporal and spatial scales.

\section{Methodology}

The study site comprises recovering Banana plantations, Sugarcane plantations, and seeded pastures at the Maquipucuna Reserve, Ecuador $\left(0^{\circ} 05^{\prime} \mathrm{N}, 78^{\circ} 37^{\prime} \mathrm{W}\right.$; http://www.maqui.org/ [53, 54, 58-61]. Maquipucuna lies between $1200 \mathrm{~m}$ and $1800 \mathrm{~m}$ and is classified as tropical lower montane wet forest [62]. It has deeply dissected drainages with steep slopes and receives between $2 \mathrm{~m}$ and $5 \mathrm{~m}$ of rainfall a year. The temperature ranges between $14^{\circ} \mathrm{C}$ and $25^{\circ} \mathrm{C}$, with an average temperature of $18^{\circ} \mathrm{C}$. The reserve's fertile Andisol soil is developed from volcanic ash deposits [42].

In June of 1996, six just abandoned agricultural fields were selected for study: two recent Sugarcane (S. officinarum) plantations denoted left and right when facing the forest
(Tables 3 and 4), two recent Banana (Musa sp.) plantations denoted left and right when facing the forest (Tables 1 and 2), and two recent pastures seeded in $S$. sphacelata denoted left and right when facing the forest (Tables 5 and 6). Although native to Africa, this Setaria grass is being planted more and more extensively in the Neotropics because it can withstand heavy grazing by spreading asexually and can form large crowns. Well accepted by cattle, the Setaria grass is tolerant of relatively cold temperatures and short-term waterlogged conditions, both common at the Maquipucuna Reserve. In each field, twenty-five $5 \mathrm{~m} \times 2 \mathrm{~m}$ contiguous plots were laid out (Figure 1). All six fields were $250 \mathrm{~m}^{2}$ rectangles located (1) within a few hundred meters of each other, (2) at the lower elevations of the reserve, and (3) with the $25 \mathrm{~m}$ plot border next to primary forest in order to facilitate comparison with the Buell-Small plot study in New Jersey, USA, which had the same design [7]. The plots did not have any remnant trees or sprouting tree roots at the beginning of the study, and their tree seed bank was very small [55].

Starting in 1997, each of the $5 \mathrm{~m} \times 2 \mathrm{~m}$ subplots of each of the six plots was sampled annually to identify each of these plant species and (1) for percent cover of each 
TABLE 2: Significant Spearman rank correlation coefficients among all plant species in the Ecuador Right Banana Plantation over the first 10 years of succession. Significant positive associations are indicated by a “+” and significant negative associations are indicated by a “-”. Plant species and families are indicated as follows: Acalypha pladichephalus (A), Costus spp. (B), Musa spp. (C), Solanum muricatum (D), Piperaceae (E), Setaria spp. (F), Tagetes terniflora (G), Begonia spp. (H), Cuphea cartagenensis (I), Polypodiaceae (J), Vernonia patens (K), Brugmansia spp. (L), Digitaria sanguinalis (M), Urticaceae (N), Chusquea spp. (O), Nectandra spp. (P), Piperaceae (Q), Commelina diffusa (R), Erythrina megistophyla (S), Heliotropium spp. (T), Inga spp. (U), Musa acuminate (V), Chenopodium album (W), Crataegus monogyna (X), Boconia frutescens $(\mathrm{Y})$, and Cecropia monostachyma $(\mathrm{Z})$.

\begin{tabular}{|c|c|c|c|c|c|c|c|c|c|c|c|c|c|c|c|c|c|c|c|c|c|c|c|c|c|}
\hline & B & $\mathrm{C}$ & $\mathrm{D}$ & $\mathrm{E}$ & $\mathrm{F}$ & $\mathrm{G}$ & $\mathrm{H}$ & I & $\mathrm{J}$ & $\mathrm{K}$ & $\mathrm{L}$ & $\mathrm{M}$ & $\mathrm{N}$ & $\mathrm{O}$ & $\mathrm{P}$ & $\mathrm{Q}$ & $\mathrm{R}$ & $S$ & $\mathrm{~T}$ & $\mathrm{U}$ & $\mathrm{V}$ & $\mathrm{W}$ & $\mathrm{X}$ & $\mathrm{Y}$ & $\bar{Z}$ \\
\hline A & + & - & - & + & + & + & + & + & + & - & + & + & + & - & + & & & & & & & & & & \\
\hline B & & + & - & + & + & + & + & - & + & + & + & + & + & + & & & & & & & & & & & \\
\hline $\mathrm{C}$ & & & + & + & + & + & + & + & + & + & + & + & + & & & & & & & & & & & & \\
\hline $\mathrm{D}$ & & & & + & + & + & + & + & + & + & + & & & & & & & & & & & & & & \\
\hline E & & & & & + & + & + & - & + & + & + & + & + & & & & & & & & & & & & \\
\hline $\mathrm{F}$ & & & & & & - & - & + & + & + & + & & & & & & & & & & & & & & \\
\hline G & & & & & & & + & + & + & + & + & + & + & + & + & & & & & & & & & & \\
\hline $\mathrm{H}$ & & & & & & & & & + & + & + & + & + & + & + & + & & & & & & & & & \\
\hline I & & & & & & & & & & + & + & + & + & + & + & + & + & + & + & & & & & & \\
\hline $\mathrm{J}$ & & & & & & & & & & & + & - & + & + & + & + & + & & & & & & & & \\
\hline $\mathrm{K}$ & & & & & & & & & & & & + & + & + & + & & & & & & & & & & \\
\hline $\mathrm{L}$ & & & & & & & & & & & & & + & + & + & + & + & + & + & + & + & + & & & \\
\hline $\mathrm{M}$ & & & & & & & & & & & & & & + & + & + & + & + & + & + & + & & & & \\
\hline $\mathrm{N}$ & & & & & & & & & & & & & & & + & + & + & + & + & & & & & & \\
\hline $\mathrm{O}$ & & & & & & & & & & & & & & & & + & + & + & & & & & & & \\
\hline $\mathrm{P}$ & & & & & & & & & & & & & & & & & + & + & + & + & + & & & & \\
\hline $\mathrm{Q}$ & & & & & & & & & & & & & & & & & + & + & + & + & + & + & + & + & + \\
\hline $\mathrm{R}$ & & & & & & & & & & & & & & & & & & + & & & & & & & \\
\hline$S$ & & & & & & & & & & & & & & & & & & & + & + & & & & & \\
\hline $\mathrm{T}$ & & & & & & & & & & & & & & & & & & & & + & + & + & + & & \\
\hline $\mathrm{U}$ & & & & & & & & & & & & & & & & & & & & & + & + & + & + & + \\
\hline V & & & & & & & & & & & & & & & & & & & & & & & & & \\
\hline W & & & & & & & & & & & & & & & & & & & & & & & + & & \\
\hline $\mathrm{X}$ & & & & & & & & & & & & & & & & & & & & & & & & + & + \\
\hline
\end{tabular}

plant species - an indication of a species' ability to capture light and, therefore, to dominate these areas in the process of becoming forested communities-estimated visually in relation to each plot's area, and (2) for diameter at breast height $(\mathrm{dbh})$ of each tree stem at least $1 \mathrm{~cm}$. Maquipucuna plant taxonomists, trained at the University of Georgia, USA, where voucher specimens are kept on file $[42,61]$, assisted in the identification of species by using specimens located on site. The 2012 sampling will mark the sixteenth year after abandonment for these fields. I have published several analyses of this dataset $[8,38,55,63-65]$.

\section{Dataset Description}

The dataset associated with this Dataset Paper consists of 12 items which are described as follows.

Dataset Item 1 (Table). Ecuador old field's percent cover file: Banana left field. It consists of five columns described as follows. The column Date is the date which the sampling took place. No data is missing for this field. Plot Number is the

\begin{tabular}{|c|c|c|c|c|}
\hline \multicolumn{6}{|c|}{ Lower montane forest } \\
\hline 1 & 2 & 3 & 4 & 5 \\
\hline 11 & 12 & 13 & 14 & 15 \\
\hline 20 & 19 & 18 & 17 & 16 \\
\hline 21 & 22 & 23 & 24 & 25 \\
\hline
\end{tabular}

FIGURE 1: Layout of each of the six $25 \mathrm{~m} \times 10 \mathrm{~m}$ plots with each of its $5 \mathrm{~m} \times 2 \mathrm{~m}$ subplots labeled as they are indicated in the datasets for each field.

subplot within the plot in the study field (see Figure 1) and is an integer between 1 and 25. Species is the scientific name of species observed. Cover Percentage (\%) is the percent cover for this species and is an integer between 0 and 100 . 
TABLE 3: Significant Spearman rank correlation coefficients among all plant species in the Ecuador Right Sugarcane Plantation over the first 10 years of succession. Significant positive associations are indicated by a "+" and significant negative associations are indicated by a "-". Plant species and families are indicated as follows: Acalypha pladichephalus (A), Asteraceae (B), Digitaria sanguinalis (C), Polypodiaceae (D), Nectandra spp. (E), Stachys micheliana (F), Piperaceae (G), Lantana camara (H), Verbenaceae (I), Erythrina megistophyla (J), Piper aduncum (K), Rubus spp. (L), Commelina diffusa (M), Elephantopus mollis (N), Cecropia spp. (O), Costus spp. (P), Miconia spp. (Q), Passifloraceae (R), Fabaceae (S), Chusquea spp. (T), Marantaceae (U), Pilea spp. (V), Hieracium spp. (W), Sabicea spp. (X), Columnea spp. (Y), and Orchidaceae (Z).

\begin{tabular}{|c|c|c|c|c|c|c|c|c|c|c|c|c|c|c|c|c|c|c|c|c|c|c|c|c|c|}
\hline & B & C & $\mathrm{D}$ & $E$ & $\mathrm{~F}$ & $\mathrm{G}$ & $\mathrm{H}$ & I & $\mathrm{J}$ & $\mathrm{K}$ & $\mathrm{L}$ & $\mathrm{M}$ & $\mathrm{N}$ & $\mathrm{O}$ & $\mathrm{P}$ & Q & $\mathrm{R}$ & S & $\mathrm{T}$ & $\mathrm{U}$ & $\mathrm{V}$ & W & $\mathrm{X}$ & $\mathrm{Y}$ & $\mathrm{Z}$ \\
\hline $\mathrm{A}$ & + & - & + & + & + & + & + & + & + & - & + & + & + & + & & & & & & & & & & & \\
\hline B & & + & + & + & + & + & + & + & - & + & + & + & + & + & + & & & & & & & & & & \\
\hline C & & & + & + & + & + & + & - & + & + & + & & & & & & & & & & & & & & \\
\hline $\mathrm{D}$ & & & & + & - & - & + & - & + & + & + & + & + & + & + & + & & & & & & & & & \\
\hline $\mathrm{E}$ & & & & & + & + & + & - & + & + & + & & & & & & & & & & & & & & \\
\hline $\mathrm{F}$ & & & & & & + & + & + & + & + & + & + & + & & & & & & & & & & & & \\
\hline G & & & & & & & + & + & + & + & & & & & & & & & & & & & & & \\
\hline $\mathrm{H}$ & & & & & & & & + & + & + & + & + & + & + & + & + & + & & & & & & & & \\
\hline I & & & & & & & & & + & + & + & + & + & + & & & & & & & & & & & \\
\hline $\mathrm{J}$ & & & & & & & & & & + & + & + & + & + & + & & & & & & & & & & \\
\hline $\mathrm{K}$ & & & & & & & & & & & + & + & + & + & + & & & & & & & & & & \\
\hline $\mathrm{L}$ & & & & & & & & & & & & - & + & + & + & + & & & & & & & & & \\
\hline $\mathrm{M}$ & & & & & & & & & & & & & + & + & + & + & + & + & & & & & & & \\
\hline $\mathrm{N}$ & & & & & & & & & & & & & & + & + & + & + & & & & & & & & \\
\hline $\mathrm{O}$ & & & & & & & & & & & & & & & + & + & & & & & & & & & \\
\hline $\mathrm{P}$ & & & & & & & & & & & & & & & & + & + & & & & & & & & \\
\hline Q & & & & & & & & & & & & & & & & & + & + & + & + & & & & & \\
\hline $\mathrm{R}$ & & & & & & & & & & & & & & & & & & + & + & + & + & & & & \\
\hline S & & & & & & & & & & & & & & & & & & + & + & + & + & + & + & + & + \\
\hline $\mathrm{T}$ & & & & & & & & & & & & & & & & & & & + & + & + & + & + & & \\
\hline $\mathrm{U}$ & & & & & & & & & & & & & & & & & & & & + & + & & & & \\
\hline V & & & & & & & & & & & & & & & & & & & & & & & & & \\
\hline W & & & & & & & & & & & & & & & & & & & & & & + & & & \\
\hline $\mathrm{X}$ & & & & & & & & & & & & & & & & & & & & & & & & & \\
\hline $\mathrm{Y}$ & & & & & & & & & & & & & & & & & & & & & & & + & & \\
\hline
\end{tabular}

Comments is the observation made at the field about the living condition of the tree. When the tree is found dead for the first time or when it sprouts, an observation is entered in this field. In the table, empty cell means missing value.

Column 1: Date

Column 2: Plot Number

Column 3: Species

Column 4: Cover Percentage (\%)

Column 5: Comments

Dataset Item 2 (Table). Ecuador old field's percent cover file: Banana right field. It consists of five columns described as follows. The column Date is the date which the sampling took place. No data is missing for this field. Plot Number is the subplot within the plot in the study field (see Figure 1) and is an integer between 1 and 25. Species is the scientific name of species observed. Cover Percentage (\%) is the percent cover for this species and is an integer between 0 and 100 . Comments is the observation made at the field about the living condition of the tree. When the tree is found dead for the first time or when it sprouts, an observation is entered in this field. In the table, empty cell means missing value.

Column 1: Date

Column 2: Plot Number

Column 3: Species

Column 4: Cover Percentage (\%)

Column 5: Comments

Dataset Item 3 (Table). Ecuador old field's percent cover file: Pasture left field. It consists of five columns described as follows. The column Date is the date which the sampling took place. No data is missing for this field. Plot Number is the subplot within the plot in the study field (see Figure 1) and is an integer between 1 and 25. Species is the scientific name 
TABLE 4: Significant Spearman rank correlation coefficients among all plant species in the Ecuador Left Sugarcane Plantation over the first 10 years of succession. Significant positive associations are indicated by a “+” and significant negative associations are indicated by a “-”. Plant species and families are indicated as follows: Musa spp. (A), Costus spp. (B), Cuphea cartagenensis (C), Digitaria sanguinalis (D), Miconia spp. (E), Piper spp. (F), Rubus spp. (G), Sida rhombifolia (H), Asteraceae (I), Baccharis spp. (J), Polypodiaceae (K), Lantana camara (L), Vernonia patens (M), Acalypha pladichephalus (N), Solanum spp. (O), Saccharum officinarum (P), Piper aduncum (Q), Verbenaceae (R), Commelina diffusa (S), Erythrina megistophyla (T), Nectandra spp. (U), Altus spp. (V), Orchidaceae (W), Polybotria spp. (X), Vernonia spp. (Y), and Polypodiaceae $(Z)$.

\begin{tabular}{|c|c|c|c|c|c|c|c|c|c|c|c|c|c|c|c|c|c|c|c|c|c|c|c|c|c|}
\hline & B & C & $\mathrm{D}$ & $\mathrm{E}$ & $\mathrm{F}$ & G & $\mathrm{H}$ & I & $\mathrm{J}$ & $\mathrm{K}$ & $\mathrm{L}$ & $\mathrm{M}$ & $\mathrm{N}$ & $\mathrm{O}$ & $\mathrm{P}$ & Q & $\mathrm{R}$ & $\mathrm{S}$ & $\mathrm{T}$ & $\mathrm{U}$ & $\mathrm{V}$ & $\mathrm{W}$ & $X$ & $\mathrm{Y}$ & $\mathrm{Z}$ \\
\hline A & + & + & - & + & - & + & + & + & + & + & + & + & + & - & + & + & + & & & & & & & & \\
\hline B & & + & + & + & + & + & + & - & + & + & + & + & + & + & + & + & & & & & & & & & \\
\hline C & & & + & + & + & + & + & + & + & + & + & + & + & + & + & + & + & + & & & & & & & \\
\hline $\mathrm{D}$ & & & & + & + & + & + & + & + & + & + & + & & & & & & & & & & & & & \\
\hline $\mathrm{E}$ & & & & & + & + & + & - & + & - & + & + & & & & & & & & & & & & & \\
\hline $\mathrm{F}$ & & & & & & + & - & + & - & - & + & - & + & + & & & & & & & & & & & \\
\hline $\mathrm{G}$ & & & & & & & + & + & + & + & + & + & + & + & + & & & & & & & & & & \\
\hline $\mathrm{H}$ & & & & & & & & + & + & + & + & - & + & + & & & & & & & & & & & \\
\hline I & & & & & & & & & + & + & + & + & + & + & + & + & & & & & & & & & \\
\hline $\mathrm{J}$ & & & & & & & & & & + & + & + & - & + & & & & & & & & & & & \\
\hline $\mathrm{K}$ & & & & & & & & & & & + & + & & & & & & & & & & & & & \\
\hline $\mathrm{L}$ & & & & & & & & & & & & + & + & + & + & + & + & + & + & + & & & & & \\
\hline $\mathrm{M}$ & & & & & & & & & & & & & + & + & + & + & + & + & + & + & & & & & \\
\hline $\mathrm{N}$ & & & & & & & & & & & & & & + & + & + & + & + & + & + & + & & & & \\
\hline $\mathrm{O}$ & & & & & & & & & & & & & & & + & + & + & + & + & + & + & & & & \\
\hline $\mathrm{P}$ & & & & & & & & & & & & & & & & + & + & + & + & & & & & & \\
\hline $\mathrm{Q}$ & & & & & & & & & & & & & & & & & + & + & + & + & + & + & & & \\
\hline $\mathrm{R}$ & & & & & & & & & & & & & & & & & & + & + & + & + & & & & \\
\hline$S$ & & & & & & & & & & & & & & & & & & & + & + & + & & & & \\
\hline $\mathrm{T}$ & & & & & & & & & & & + & + & + & + & + & + & + & + & + & + & + & + & + & + & + \\
\hline $\mathrm{U}$ & & & & & & & & & & & & & & & & & & & & & + & & & & \\
\hline
\end{tabular}

TABLE 5: Significant Spearman rank correlation coefficients among all plant species in the Ecuador Left Pasture over the first 10 years of succession. Significant positive associations are indicated by a " + " and significant negative associations are indicated by a "-". Plant species and families are indicated as follows: Setaria sphacelata (A), Acalypha pladichephalus (B), Xanthosoma sagittifolia (C), Heliocarpus americanus (D), Heliconia spp. (E), Ficus spp. (F), Solanceae $(\mathrm{G})$, Araceae (H), Citrus spp. (I), Vernonia patens (J), Begonia spp. (K), and Nectandra spp. (L).

\begin{tabular}{llllllllllll}
\hline & $\mathrm{B}$ & $\mathrm{C}$ & $\mathrm{D}$ & $\mathrm{E}$ & $\mathrm{F}$ & $\mathrm{G}$ & $\mathrm{H}$ & $\mathrm{I}$ & $\mathrm{J}$ & $\mathrm{K}$ & $\mathrm{L}$ \\
\hline $\mathrm{A}$ & - & - & - & - & - & - & - & - & - & - & \\
$\mathrm{B}$ & + & + & + & + & + & + & + & + & + & + & + \\
$\mathrm{C}$ & & & + & + & & & & & & & \\
$\mathrm{D}$ & & & & & & & & & & & \\
$\mathrm{E}$ & & & & & & & & & & & \\
$\mathrm{F}$ & & & & & & & & & & & \\
\hline
\end{tabular}

of species observed. Cover Percentage (\%) is the percent cover for this species and is an integer between 0 and 100 . Comments is the observation made at the field about the living condition of the tree. When the tree is found dead for the first time or when it sprouts, an observation is entered in this field. In the table, empty cell means missing value.
TABlE 6: Significant Spearman rank correlation coefficients among all plant species in the Ecuador Right Pasture over the first 10 years of succession. Significant positive associations are indicated by a "+" and significant negative associations are indicated by a "-". Plant species and families are indicated as follows: Setaria sphacelata (A), Erythrina megistophyla (B), and Polpodiaceae (C).

\begin{tabular}{lll}
\hline & $\mathrm{B}$ & $\mathrm{C}$ \\
\hline $\mathrm{A}$ & - & - \\
\hline
\end{tabular}

Column 1: Date

Column 2: Plot Number

Column 3: Species

Column 4: Cover Percentage (\%)

Column 5: Comments

Dataset Item 4 (Table). Ecuador old field's percent cover file: Pasture right field. It consists of five columns described as follows. The column Date is the date which the sampling took place. No data is missing for this field. Plot Number is the subplot within the plot in the study field (see Figure 1) and is an integer between 1 and 25. Species is the scientific name of species observed. Cover Percentage (\%) is the percent 
cover for this species and is an integer between 0 and 100 . Comments is the observation made at the field about the living condition of the tree. When the tree is found dead for the first time or when it sprouts, an observation is entered in this field. In the table, empty cell means missing value.

Column 1: Date

Column 2: Plot Number

Column 3: Species

Column 4: Cover Percentage (\%)

Column 5: Comments

Dataset Item 5 (Table). Ecuador old field's percent cover file: Sugarcane left field. It consists of five columns described as follows. The column Date is the date which the sampling took place. No data is missing for this field. Plot Number is the subplot within the plot in the study field (see Figure 1) and is an integer between 1 and 25. Species is the scientific name of species observed. Cover Percentage (\%) is the percent cover for this species and is an integer between 0 and 100 . Comments is the observation made at the field about the living condition of the tree. When the tree is found dead for the first time or when it sprouts, an observation is entered in this field. In the table, empty cell means missing value.

Column 1: Date

Column 2: Plot Number

Column 3: Species

Column 4: Cover Percentage (\%)

Column 5: Comments

Dataset Item 6 (Table). Ecuador old field's percent cover file: Sugarcane right field. It consists of five columns described as follows. The column Date is the date which the sampling took place. No data is missing for this field. Plot Number is the subplot within the plot in the study field (see Figure 1) and is an integer between 1 and 25. Species is the scientific name of species observed. Cover Percentage (\%) is the percent cover for this species and is an integer between 0 and 100 . Comments is the observation made at the field about the living condition of the tree. When the tree is found dead for the first time or when it sprouts, an observation is entered in this field. In the table, empty cell means missing value.

Column 1: Date

Column 2: Plot Number

Column 3: Species

Column 4: Cover Percentage (\%)

Column 5: Comments

Dataset Item 7 (Table). Ecuador old field's percent tree stem file: Banana left field. It consists of seven columns described as follows. The column Date is the date which the sampling took place. No data is missing for this field. Plot Number is the subplot within the plot in the study field (see Figure 1) and is an integer between 1 and 25. Tag Number is a unique number for each main stem in the entire LFDP. The main stem tag number is the number for an individual plant. No data is missing in this field. Species is the scientific name of species observed. Height is the height measured before cutting stem. Basal Diameter is the diameter at breast height of the tree and has a minimum of $1 \mathrm{~cm}$. Comments is the observation made at the field about the living condition of the tree. When the tree is found dead for the first time or when it sprouts, an observation is entered in this field. In the table, empty cell means missing value.

\author{
Column 1: Date \\ Column 2: Plot Number \\ Column 3: Tag Number \\ Column 4: Species \\ Column 5: Height (cm) \\ Column 6: Basal Diameter $(\mathrm{cm})$ \\ Column 7: Comments
}

Dataset Item 8 (Table). Ecuador old field's percent tree stem file: Banana right field. It consists of seven columns described as follows. The column Date is the date which the sampling took place. No data is missing for this field. Plot Number is the subplot within the plot in the study field (see Figure 1) and is an integer between 1 and 25. Tag Number is a unique number for each main stem in the entire LFDP. The main stem tag number is the number for an individual plant. No data is missing in this field. Species is the scientific name of species observed. Height is the height measured before cutting stem. Basal Diameter is the diameter at breast height of the tree and has a minimum of $1 \mathrm{~cm}$. Comments is the observation made at the field about the living condition of the tree. When the tree is found dead for the first time or when it sprouts, an observation is entered in this field. In the table, empty cell means missing value.
Column 1: Date
Column 2: Plot Number
Column 3: Tag Number
Column 4: Species
Column 5: Height (cm)
Column 6: Basal Diameter $(\mathrm{cm})$
Column 7: Comments

Dataset Item 9 (Table). Ecuador old field's percent tree stem file: Pasture left field. It consists of seven columns described as follows. The column Date is the date which the sampling took place. No data is missing for this field. Plot Number is the subplot within the plot in the study field (see Figure 1) and is an integer between 1 and 25. Tag Number is a unique number for each main stem in the entire LFDP. The main stem tag number is the number for an individual plant. No data is missing in this field. Species is the scientific name of species observed. Height is the height measured before cutting stem. 
Basal Diameter is the diameter at breast height of the tree and has a minimum of $1 \mathrm{~cm}$. Comments is the observation made at the field about the living condition of the tree. When the tree is found dead for the first time or when it sprouts, an observation is entered in this field. In the table, empty cell means missing value.

Column 1: Date

Column 2: Plot Number

Column 3: Tag Number

Column 4: Species

Column 5: Height $(\mathrm{cm})$

Column 6: Basal Diameter (cm)

Column 7: Comments

Dataset Item 10 (Table). Ecuador old field's percent tree stem file: Pasture right field. It consists of seven columns described as follows. The column Date is the date which the sampling took place. No data is missing for this field. Plot Number is the subplot within the plot in the study field (see Figure 1) and is an integer between 1 and 25. Tag Number is a unique number for each main stem in the entire LFDP. The main stem tag number is the number for an individual plant. No data is missing in this field. Species is the scientific name of species observed. Height is the height measured before cutting stem. Basal Diameter is the diameter at breast height of the tree and has a minimum of $1 \mathrm{~cm}$. Comments is the observation made at the field about the living condition of the tree. When the tree is found dead for the first time or when it sprouts, an observation is entered in this field. In the table, empty cell means missing value.

Column 1: Date

Column 2: Plot Number

Column 3: Tag Number

Column 4: Species

Column 5: Height (cm)

Column 6: Basal Diameter $(\mathrm{cm})$

Column 7: Comments

Dataset Item 11 (Table). Ecuador old field's percent tree stem file: Sugarcane left field. It consists of seven columns described as follows. The column Date is the date which the sampling took place. No data is missing for this field. Plot Number is the subplot within the plot in the study field (see Figure 1) and is an integer between 1 and 25. Tag Number is a unique number for each main stem in the entire LFDP. The main stem tag number is the number for an individual plant. No data is missing in this field. Species is the scientific name of species observed. Height is the height measured before cutting stem. Basal Diameter is the diameter at breast height of the tree and has a minimum of $1 \mathrm{~cm}$. Comments is the observation made at the field about the living condition of the tree. When the tree is found dead for the first time or when it sprouts, an observation is entered in this field. In the table, empty cell means missing value

Column 1: Date

Column 2: Plot Number

Column 3: Tag Number

Column 4: Species

Column 5: Height (cm)

Column 6: Basal Diameter (cm)

Column 7: Comments

Dataset Item 12 (Table). Ecuador old field's percent tree stem file: Sugarcane right field. It consists of seven columns described as follows. The column Date is the date which the sampling took place. No data is missing for this field. Plot Number is the subplot within the plot in the study field (see Figure 1) and is an integer between 1 and 25. Tag Number is a unique number for each main stem in the entire LFDP. The main stem tag number is the number for an individual plant. No data is missing in this field. Species is the scientific name of species observed. Height is the height measured before cutting stem. Basal Diameter is the diameter at breast height of the tree and has a minimum of $1 \mathrm{~cm}$. Comments is the observation made at the field about the living condition of the tree. When the tree is found dead for the first time or when it sprouts, an observation is entered in this field. In the table, empty cell means missing value.

Column 1: Date

Column 2: Plot Number

Column 3: Tag Number

Column 4: Species

Column 5: Height $(\mathrm{cm})$

Column 6: Basal Diameter (cm)

Column 7: Comments

\section{Concluding Remarks}

The establishment and regular sampling of permanent plots have proven invaluable in the investigation of areas recovering back to forest after cultivation. In particular here in the Americas, such plots have been a major part of those investigations $[9,38]$. With the assistance of the LTER program, I will continue that monitoring in fields recovering from the common Neotropical crops of Sugarcane, Banana, and seeded pasture.

\section{Dataset Availability}

The dataset associated with this Dataset Paper is dedicated to the public domain using the CC0 waiver and is available at http://dx.doi.org/10.7167/2013/468973/dataset. In addition, all the data from the six plots are housed in the archives of the Luquillo (LUQ) Experimental Forest, which is a Long-Term 
Ecological Research (LTER) site, as LTERDATB\#101. One may visit their website (http://luq.lternet.edu/) for access.

\section{Conflict of Interests}

There is no conflict of interests in the access or publication of this dataset.

\section{Acknowledgments}

The author thanks N. V. L. Brokaw and the LUQ LTER for their continuing support of the sampling of the six study fields. He also thanks Eda Melendez, John Monte, and the staff of the LUQ LTER for their work in maintaining the LTER dataset. He received support from the National Science Foundation Grants DEB-9411973 and DEB-0218039 awarded to the Institute for Tropical Ecosystem Studies, University of Puerto Rico, and to the International Institute of Tropical Forestry as part of the Long-Term Ecological Research Program in the LUQ Experimental Forest, and from the National Geographic Society Grant no. 6168-98. Additional support was provided by the USDA Forest Service, International Institute of Tropical Forestry, as part of the Long-Term Ecological Research Program in the Luquillo Experimental Forest and the University of Puerto Rico.

\section{References}

[1] R. W. Myster and S. T. A. Pickett, "Initial conditions, history and successional pathways in ten contrasting old fields," American Midland Naturalist, vol. 124, no. 2, pp. 231-238, 1990.

[2] R. W. Myster and S. T. A. Pickett, "A comparison of rate of succession over 18 yr in 10 contrasting old fields," Ecology, vol. 75, no. 2, pp. 387-392, 1994.

[3] F. E. Egler, "Vegetation science concepts I. Initial floristic composition, a factor in old-field vegetation development with 2 figs," Vegetatio, vol. 4, no. 6, pp. 412-417, 1954.

[4] D. Tilman, Plant Strategies and the Dynamics and Structure of Plant Communities. Princeton, Princeton University Press, Princeton, NJ, USA, 1988.

[5] R. W. Myster and M. P. Malahy, "Is there a middle way between permanent plots and chronosequences?" Canadian Journal of Forest Research, vol. 38, no. 12, pp. 3133-3138, 2008.

[6] M. F. Buell, H. F. Buell, J. A. Small, and T. G. Siccama, "Invasion of trees in secondary succession on the New Jersey piedmont," Bulletin of the Torrey Botanical Club, vol. 98, pp. 67-74, 1971.

[7] R. W. Myster and S. T. A. Pickett, "The Buell successional study at Hutcheson Memorial Forest center," Permanent Plotter, vol. 3, pp. 2-3, 1990.

[8] R. W. Myster and S. T. A. Pickett, "Dynamics of associations between plants in ten old fields during 31 years of succession," Journal of Ecology, vol. 80, no. 2, pp. 291-302, 1992.

[9] R. W. Myster, "Tree invasion and establishment in old fields at Hutcheson Memorial Forest," Botanical Review, vol. 59, no. 4, pp. 251-272, 1993.

[10] F. A. Bazzaz, Plants in Changing Environments: Linking Physiological, Population, and Community Ecology, Cambridge University Press, Cambridge, UK, 1996.

[11] B. Finegan, "Forest succession," Nature, vol. 312, no. 5990, pp. 109-114, 1984.
[12] H. J. Oosting, "An ecological analysis of the plant communities of Piedmont, North Carolina," American Midland Naturalist, vol. 28, pp. 1-126, 1942.

[13] F. A. Bazzaz, "Succession on abandoned fields in the Shawnee Hills, southern Illinois," Ecology, vol. 49, no. 5, pp. 924-936, 1968.

[14] S. T. A. Pickett, "Population patterns through twenty years of old field succession," Vegetatio, vol. 49, no. 1, pp. 45-59, 1982.

[15] I. Castro, A. Sterling, and E. F. Galiano, "Multi-species pattern analysis of Mediterranean pastures in three stages of ecological succession," Vegetatio, vol. 68, no. 1, pp. 37-42, 1986.

[16] J. Miles, Vegetation Dynamics, John Wiley \& Sons, New York, NY, USA, 1979.

[17] A. Borhidi, "Vegetation dynamics of the savannization process on Cuba," Vegetatio, vol. 77, no. 1-3, pp. 177-183, 1988.

[18] R. W. Myster, "Post-agricultural ecotones in Puerto Rico," in Ecotones between Forest and Grassland, R. W. Myster, Ed., pp. 111-137, Springer, Berlin, Germany, 2012.

[19] A. Grainger, "Estimating areas of degraded tropical lands requiring replenishment of forest cover," International Tree Crops Journal, vol. 5, no. 1-2, pp. 31-61, 1988.

[20] P. M. Fearnside, "Deforestation in Brazilian Amazonia: the effect of population and land tenure," Ambio, vol. 22, no. 8, pp. 537-545, 1993.

[21] D. Skole and C. Tucker, "Tropical deforestation and habitat fragmentation in the amazon: satellite data from 1978 to 1988," Science, vol. 260, no. 5116, pp. 1905-1910, 1993.

[22] R. J. Buschbacher, "Tropical deforestation and pasture development," BioScience, vol. 36, pp. 2-28, 1986.

[23] C. Uhl, R. Buschbacher, and E. A. S. Serrao, "Abandoned pastures in eastern Amazonia. I. Patterns of plant succession," Journal of Ecology, vol. 76, no. 3, pp. 663-681, 1988.

[24] J. R. Thomlinson, M. I. Serrano, T. D. M. López, T. M. Aide, and J. K. Zimmerman, "Land-use dynamics in a post-agricultural Puerto Rican landscape (1936-1988)," Biotropica, vol. 28, no. 4, pp. 525-536, 1996.

[25] P. Donfack, C. Floret, and R. Pontanier, "Secondary succession in abandoned fields of dry tropical Northern Cameroon," Journal of Vegetation Science, vol. 6, no. 4, pp. 499-508, 1995.

[26] D. N. Fernandes and R. L. Sanford, "Effects of recent land-use practices on soil nutrients and succession under tropical wet forest in Costa Rica," Conservation Biology, vol. 9, no. 4, pp. 915-922, 1995.

[27] P. F. Quintana-Ascencio, M. González-Espinosa, N. RamírezMarcial, G. Domínguez-Vázquez, and M. Martínez-Icó, "Soil seed banks and regeneration of tropical rain forest from milpa fields at the Selva Lacandona, Chiapas, Mexico," Biotropica, vol. 28, no. 2, pp. 192-209, 1996.

[28] S. Brown and A. E. Lugo, "Tropical secondary forests," Journal of Tropical Ecology, vol. 6, no. 1, pp. 1-32, 1990.

[29] N. Myers, "Tropical deforestation: the last situation," BioScience, vol. 41, p. 282, 1991.

[30] K. D. Singh, "The 1990 tropical forest resources assessment," Unasylva, vol. 174, pp. 10-19, 1993.

[31] A. E. Lugo, "Comparison of tropical tree plantations with secondary forests of similar age," Ecological Monographs, vol. 62, no. 1, pp. 1-41, 1992.

[32] E. S. A. Serrao and J. M. Toledo, "The search for sustainability in Amazonian pastures," in Alternatives to Deforestation: Steps Toward Sustainable Use of the Amazon Rain Forest, A. B. 
Anderson, Ed., pp. 195-214, Columbia University Press, New York, NY, USA, 1990.

[33] T. M. Aide and J. Cavelier, "Barriers to lowland tropical forest restoration in the Sierra Nevada de Santa Marta, Colombia," Restoration Ecology, vol. 2, no. 4, pp. 219-229, 1994.

[34] C. Padoch and A. P. Vayda, "Patterns of resource use and human settlement in tropical forest," in Tropical Rain Forest Ecosystems, F. B. Golley, Ed., vol. A, pp. 301-313, Elsevier, New York, NY, USA, 1983.

[35] S. E. Hobbie, "Effects of plant species on nutrient cycling," Trends in Ecology and Evolution, vol. 7, no. 10, pp. 336-339, 1992.

[36] D. J. Mabberley, Tropical Rain Forest Ecology, Chapman and Hall, New York, NY, USA, 1992.

[37] M. Keller, E. Veldkamp, A. M. Weitz, and W. A. Reiners, "Effect of pasture age on soil trace-gas emissions from a deforested area of Costa Rica," Nature, vol. 365, no. 6443, pp. 244-246, 1993.

[38] R. W. Myster, "Introduction," in Post-Agricultural Succession in the Neotropics, R. W. Myster, Ed., Springer, Berlin, Germany, 2007.

[39] C. Raunkaier, The Life forms of Plants and Statistical Plant Geography, Clarendon Press, Oxford, UK, 1934.

[40] S. T. A. Pickett and P. S. White, The Ecology of Natural Disturbance and Patch Dynamics, Academic Press, Orlando, Fla, USA, 1985.

[41] R. W. Myster and L. R. Walker, "Plant successional pathways on Puerto Rican landslides," Journal of Tropical Ecology, vol. 13, no. 2, pp. 165-173, 1997.

[42] R. W. Myster and F. O. Sarmiento, "Seed inputs to microsite patch recovery on two tropandean landslides in Ecuador," Restoration Ecology, vol. 6, no. 1, pp. 35-43, 1998.

[43] E. M. Everham, R. W. Myster, and E. Vandegenachte, "Effects of light, moisture, temperature, and litter on the regeneration of five tree species in the tropical montane wet forest of Puerto Rico," American Journal of Botany, vol. 83, no. 8, pp. 1063-1068, 1996.

[44] N. V. L. Brokaw, "The definition of treefall gap and its effect on measures of forest dynamics," Biotropica, vol. 14, pp. 158-160, 1982.

[45] C. Staver, "Why farmers rotate fields in maize-cassava-plantain bush fallow agriculture in the wet Peruvian Amazon," Human Ecology, vol. 17, no. 4, pp. 401-426, 1989.

[46] R. W. Myster and S. T. A. Pickett, "Individualistic patterns of annuals and biennials in early successional old fields," Vegetatio, vol. 78, no. 1-2, pp. 53-60, 1988.

[47] C. Uhl, "Factors controlling succession following slash-andburn agriculture in Amazonia," Journal of Ecology, vol. 75, no. 2, pp. 377-407, 1987.

[48] P. J. Grubb, "The maintenance of species richness in plant communities: the importance of the regeneration niche," Biological Review, vol. 52, no. 1, pp. 107-145, 1977.

[49] R. T. Busing, "Estimation of tree replacement patterns in an Appalachian Picea-Abies forest," Journal of Vegetation Science, vol. 7, no. 5, pp. 685-694, 1996.

[50] R. W. Myster, "Plants replacing plants: the future of community modeling and research," The Botanical Review, vol. 78, pp. 2-9, 2012.

[51] R. W. Myster and B. C. McCarthy, "Effects of herbivory and competition on survival of Carya tomentosa (Juglandaceae) seedlings," Oikos, vol. 56, no. 2, pp. 145-148, 1989.
[52] R. W. Myster and S. T. A. Pickett, "Effects of litter, distance, density and vegetation patch type on postdispersal tree seed predation in old fields," Oikos, vol. 66, no. 3, pp. 381-388, 1993.

[53] R. W. Myster, "Regeneration filters in post-agricultural fields of Puerto Rico and Ecuador," Plant Ecology, vol. 172, no. 2, pp. 199-209, 2004.

[54] R. W. Myster, "Post-agricultural invasion, establishment, and growth of neotropical trees," Botanical Review, vol. 70, no. 4, pp. 381-402, 2004.

[55] R. W. Myster, "Early successional pattern and process after sugarcane, banana, and pasture cultivation in Ecuador," The New Zealand Journal of Botany, vol. 45, no. 1, pp. 101-110, 2007.

[56] R. H. Whittaker, Communities and Ecosystems, Macmillan, New York, NY, USA, 1975.

[57] J. L. Harper, Population Biology of Plants, Academic Press, London, UK, 1977.

[58] F. O. Sarmiento, "Arrested succession in pastures hinders regeneration of Tropandean forests and shreds mountain landscapes," Environmental Conservation, vol. 24, no. 1, pp. 14-23, 1997.

[59] C. C. Rhoades, G. E. Eckert, and D. C. Coleman, "Effect of pasture trees on soil nitrogen and organic matter: implications for tropical montane forest restoration," Restoration Ecology, vol. 6, no. 3, pp. 262-270, 1998.

[60] C. C. Rhoades and D. C. Coleman, "Nitrogen mineralization and nitrification following land conversion in montane Ecuador," Soil Biology and Biochemistry, vol. 31, no. 10, pp. 1347-1354, 1999.

[61] R. A. Zahawi and C. K. Augspurger, "Early plant succession in abandoned pastures in Ecuador," Biotropica, vol. 31, no. 4, pp. 540-552, 1999.

[62] J. Edmisten, "Some autoecological studies of Ormosia krugii," in A Tropical Rain Forest, H. T. Odum and R. F. Pigeon, Eds., Chapter D-8, National Technical Information Service, Virginia, Va, USA, 1970.

[63] R. W. Myster, "Are productivity and richness related consistently after different crops in the Neotropics?” Botany, vol. 87, no. 4, pp. 357-362, 2009.

[64] R. W. Myster, “Testing dominance-diversity hypotheses using data from abandoned plantations and pastures in Puerto Rico and Ecuador," Journal of Tropical Ecology, vol. 26, no. 2, pp. 247-250, 2010.

[65] R. W. Myster, "A refined methodology for defining plant communities using postagricultural data from the Neotropics," The Scientific World Journal, vol. 2012, Article ID 365409, 9 pages, 2012. 

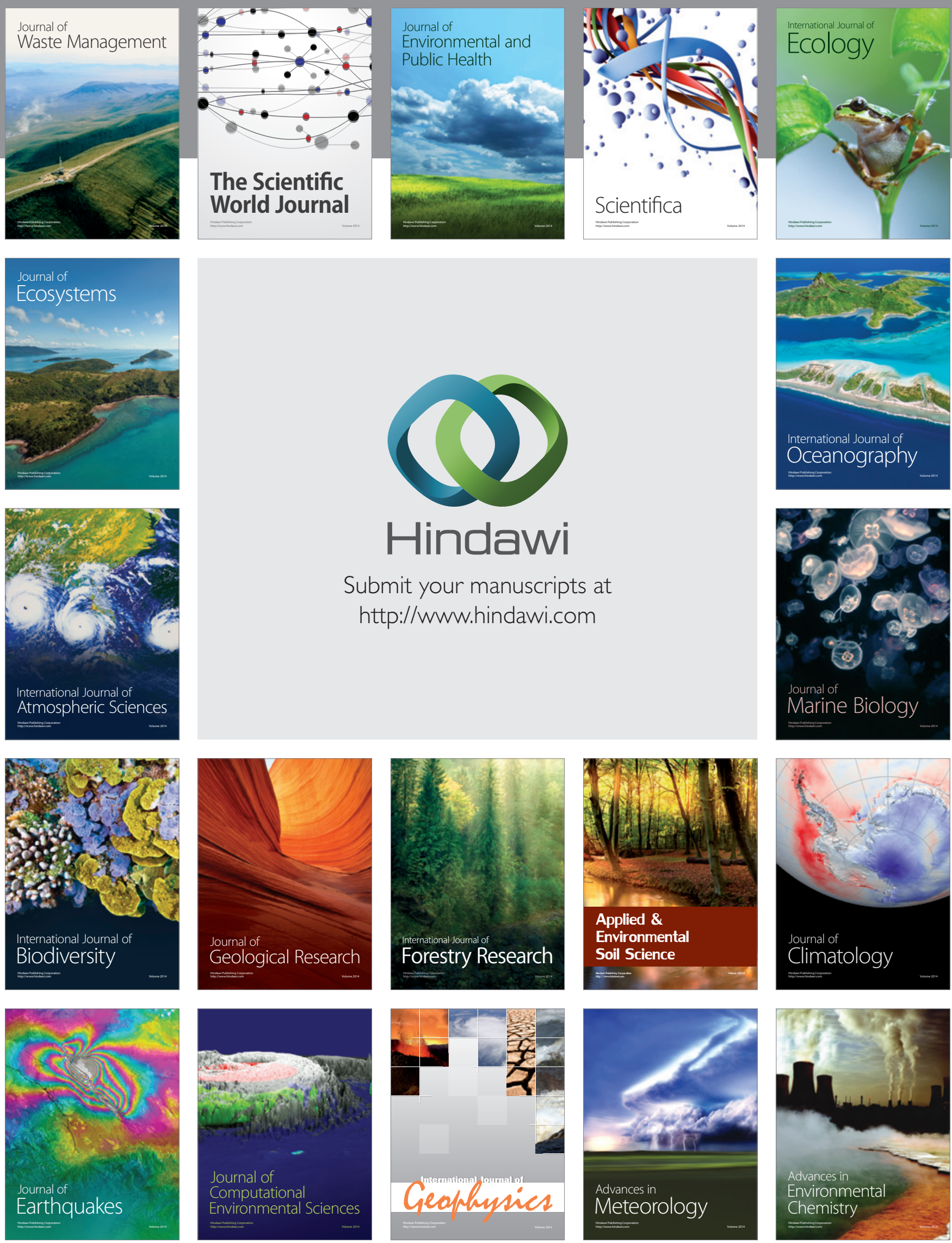